\title{
Consumption as Sign in Don DeLillo's Cosmopolis
}

\author{
Seyyede Fateme Mirbabazade (Corresponding author) \\ Faculty of Humanities, Department of English Language and Literature \\ Shahid Beheshti University, Tehran, Iran \\ Tel: +98914-441-58-30 E-mail: Fateme_Mirbabazade@yahoo.com \\ Alireza Jafari \\ Faculty of Humanities, Department of English Language and Literature \\ Shahid Beheshti University, Tehran, Iran \\ E-mail: Jafari45@yahoo.com
}

Received: 01-07-2013

Accepted: 10-08-2013

Published: 01-11-2013

doi:10.7575/aiac.ijalel.v.2n.6p.67

URL: http://dx.doi.org/10.7575/aiac.ijalel.v.2n.6p.67

\begin{abstract}
As one of the foremost American postmodern authors, Don DeLillo tends to focus on construction of postmodern subject's consciousness through media, technology and consumption. Nevertheless, despite many affinities between Baudrillard and DeLillo, many researches which have been done on his works have failed to theoretically analyze them from Baudrillardian perspective. Although there is affinity between Baudrillard and DeLillo, there is dissimilarity as well. While Baudrillard believes that that there is no escape for individual from the ideology of the system, DeLillo claims that there is hope for change and revolution for the individuals by their action in society, particularly by the means of art, to be more than a cog in the machine of ideology of system. Baudrillard, as one of the most influential postmodern theorists, defines consumption as organized control of sign and one of the many ways any subject is assimilated in any given society. For Baudrillard the logic of consumption is based on social differentiation. By the logic of social differentiation, individuals distinguish themselves and obtain social prestige and standing through the purchase and use of consumer goods. In his theorization about the concept of need and value, Baudrillard finds Marx's logics of use value (utility and functionality) and exchange value (economic value) inadequate to include the whole function of an object and adds the logic of sign value. Baudrillard asserts that in consumption economic exchange value (money) is transformed into sign exchange value (prestige, etc.); yet this functioning is maintained by the use value. The only way out of this dilemma, Baudrillard claims, is to return to symbolic exchange which is neither a conception nor an agency, but an act of exchange and a social relation and the only approach to real human communication and understanding. Therefore this research attempts to highlights those affinities in DeLillo's first post-9/11 novel a.k.a. Cosmopolis.
\end{abstract}

Keywords: Baudrillard, Don DeLillo, Cosmopolis, sign value, exchange value, symbolic exchange

\section{Introduction}

Today, consumerism is our ideology, the current model of post-modernity (Norris); however, as a term, consumerism has been recognized as destructive of political life and deformative of human consciousness, interpreted as a process by which the human being is "dehumanized and depoliticized"- an active individual replaced with arrogant consumers and passive spectators (Norris). As one of the main specification of consumerism, consumption has become our primary language, literacy the interpretation of commercial symbols; and, the act of consumption becomes our primary mode of insertion into the world and experience of participation in something beyond ourselves.

An understanding of consumerism can be taken from one of the influential critics of this notion, Jean Baudrillard who asserts that consumerism,

...does not affluence ultimately only have meaning in wastage... wastage which defies scarcity and, contradictorily, signifies abundance ... The consumer society needs objects in order to be. More precisely, it needs to destroy them...destruction remains the fundamental alternative to production: consumption is merely an intermediate term between the two. (Baudrillard, 1996, p. 44-45, 47 original emphasis)

In another place, Baudrillard considers act of consuming and consumption as a profound aspect of our society as he points out:

With the advent of consumer society, we are seemingly faced for the first time in history by an irreversible organized attempt to swamp society with objects and integrate it into an indispensable system designed to replace all open interaction between natural forces, needs and techniques. (Baudrillard, 1996, p.132) 
Baudrillard notifies that there is a whole new emergence of a social order with consumption at its center, that it is reflected in us and also in our understanding of ourselves (Norris, 2005). In this vein, in another way of interpretation, Jane Kenway asserts that "consumerism is now identified as a defining characteristic of the lifestyle of the Western world". Consumerism is then the release of our creative and destructive capacities, what Joseph Schumpeter calls "creative destruction" (quoted in Norris). We are thus not only consuming products but also in the process of consumption "use up" and negate something fundamental within ourselves and our life, in a way that in our pursuit for possession of things, we experience an absence rather than fulfillment. While much more can be said about consumption, there are some essential, uncontroversial facts about it: we have always engaged in consumption since our early times; second, our survival depends on consumption; third, we are all consumers in some way or another.

It should be indicated that, upon its publication in 2003, Cosmopolis was considered a major literary flop and did not well-received by critics. Michiko Kakutani in an unfavorable review called it "a clichéd attempt" that amounts to a "comic-strip capitalist pig" story (Headed toward a Crash). In the same line, John Updike, in his review for New Yorker, argues that in Cosmopolis "implausibility reigns unchecked, mounting to a phantasmagoric funeral parade" (One-way Street).Many reviews on Cosmopolis have read the novel as a story of a corrupted capitalist and violator of corporate ethics. Russell Scott Valentino regards the novel as a lesson on the decline of virtue in postmodern capitalist society, and Jerry A. Varsava argues that Eric's breach of fiduciary commitment is outrageous enough to render him as embodiment of evil. On the other side of the spectrum, there are critics like Peter Boxall, David Cowart and Joseph Conte, claim that Cosmopolis, DeLillo's first post-9/11 novel, cannot be read other than in relation to terrorist attacks of 11 September 2001.

Considering all the various commentaries and reading, this research, with recourse to Baudrillard theories, analyzes characteristics of consumption, the ideology behind it and also its function in society and how it influences human's relation with objects. It will be emphasized how consumption's virulent effects hinder real meaningful communication between individuals and how individual personalization and identity is determined by the commodities they possess. Likewise, with the ever increasing commodification of needs, relations and the presence of objects in everyday human lives, the need for ways, strategies that lead to true human relations will be highlighted. Therefore, in this essay Baudrillard's theories are examined in three main parts which each of them has its own subdivisions: Consumer Society, Symbolic Exchange, and Consumer Culture; after each analysis, there is an example of DeLillo's Cosmopolis to demonstrate the close relationship between his novel and Baudrillard's consumption theory.

\section{Discussion}

\subsection{Consumer (postmodern) Society}

In general speaking, consumerism demands the institutionalized production of need and the invention of new desires, the systematic indoctrination of inadequacy and yearning for wholeness through material satisfaction. Yet, there are different views concerning the origin and emergence of consumerism. Some scholars associate it with capitalism and consider consumerism as a response to capitalism's homogenizing force. Therefore, as a result, people began to consume as a "mode of self-expression", a kind of "common language through which we communicate and interpret shared cultural signs". Other scholars consider it as a phenomenon connected with the rise of communication (Norris, 2005).

According to this view, consumerism is a prominent mode of self-expression, participation, and sense of belonging in an era when traditional concepts of belonging such as religion, family, has been eroded (Bocock, cited in Norris). Still other critics link its emergence with the ever-going desire for change and innovation, in react to the rapid obsolescence of the old and quest for the new. And finally, it has been depicted as a process by which individual energy for political resistance is exhausted and, instead, is oriented toward personal material gratification and toward indifference to alienation (Norris, 2005).

In the analysis of consumer society, Baudrillard draws from the disciplines of semiotics, psychoanalysis and the political economy of the production of signs. Likewise, he draws on the theorists of consumer society such as, Herbert Marcuse, Emile Durkheim, Daniel Boorstin, and Thorstein Veblen in his theorizing about the nature of commodities and objects. In drawing from these areas, Baudrillard provides an extensive analysis of the various dimensions of consumption (Norris, 2005).In fact, postmodern society and consumption, for some critics, is synonymous with consumer society (Baudrillard, 1996, p. 1).

It should be noted that it is in the backdrop of consumption that Baudrillard's many theories and themes such as ambivalence, sign-value, fetishism, recycling and many other theories take shape in Consumer Society. It touches upon various issues, but above all, it is about consumption. In Consumer Society, consumption for Baudrillard is not confined to buying certain commodities or fulfilling of needs, but it is

an order of significations in a 'panoply' of objects; a system, or code, of signs; an order of the manipulation of signs(reference); a systematic production of signs; the manipulation of objects as signs; a communication system (like a language); a system of exchange (like primitive kinship); a morality, that is a system of ideological values; a social function; a structural organization; a collective phenomenon; the production of differences; a generalization of the combinatorial processes of fashion'; isolating and individualizing; an unconscious constraint on people, both from the sign system and from the socio-economico-political system; and a social logic. (Baudrillard, 1998, p.15) 
Douglas Kellner, in Jean Baudrillard: From Marxism to Postmodernism and Beyond, proposes that, for Baudrillard consumption is a socio-cultural concept which stresses the way in which society produces needs through "socialization and conditioning thereby managing consumer demand and consumption" (15). Baudrillard gives a new description of world of consumption as:

We are surrounded by the remarkable conspicuousness of consumption and affluence, established by the multiplication of objects, services and material goods, all of which constitutes a sort of fundamental mutation in the ecology of the human species. Strictly speaking, these affluent individuals are no longer surrounded by other human beings as they were in the past, but by objects. (Baudrillard, 1998, p. 17; Baudrillard, 2001, p. 29 original emphasis)

Baudrillard points to the inability of meaningful exchange in consumer society and adds that "The arbitrariness of the sign begins when, instead of bonding two persons in an inescapable reciprocity, the signifier starts to refer to a disenchanted universe of the signified, the common denominator of the real world, towards which no-one any longer has the least obligation" (Baudrillard, 2000, p. 51). Baudrillard, moreover, puts forward his assertion that, in postmodern society of consumption, people increasingly exchange visual signs with one another. Value is no longer connected to an object's use value or exchange value, but to its sign value (Armitage, 2007).Therefore, according to Baudrillard, modernity marks the production of objects and commodities and postmodernity marks the production of signs of difference; a new society of signs, images and codes surfaces with the advent of postmodernism. For Baudrillard, thus, consumer society is organized and controlled by value. It can be read as a single text in which every element functions as a sign of value. Value is an ideological construct that perplexes social relations and hinders meaningful exchange (Schuster, 2008, p. 74).In the first analysis of the novel, as a result, the value is exercised in three parts, Sign, Symbolic\& Exchange and Symbolic Exchange.

\subsubsection{Value}

For Baudrillard the controlling concept in the system of signs of the consumer society is value, and the most basic sign is money. Yet, he argues that the idea of value is meaningless because value like hyperreality has no point of reference. As a result, value, for Baudrillard, is nothing but an abstract meaning for measuring political economy, and money becomes "speculative", a "floating signifier" with no real signified to "serve as a brake to its proliferation and unlimited play" (Baudrillard, 2000, p. 22).

In relation to DeLillo, this idea is displayed throughout the Cosmopolis when Eric's "actions regarding the yen were causing storms of disorder. He was so leveraged, his firm's portfolio large and sprawling, linked crucially to the affairs of so many key institutions, all reciprocally vulnerable, that the whole system was in danger" (DeLillo, 2003, p.49). Value, as Baudrillard argues, is the illusion behind consumer ideology that renders significant otherwise insignificant objects and persuades individuals to accumulate large quantities of commodities (Baudrillard, 1998, p. 82).This concept is made clear in Cosmopolis as Vija Kinski, Eric's chief of theory, in relation between Eric's home and its price says:

What did you buy for your one hundred and four million dollars? Not dozens of rooms, incomparable views, private elevators. Not the rotating bedroom and computerized bed. Not the swimming pool or the shark. Was it air rights? The regulating sensors and software? Not the mirrors that tell you how to feel when you look at yourself in the morning. You paid the money for the number itself. One hundred and four million. This is what you bought. And it's worth it. The number justifies itself. (DeLillo, 2003, p. 78)

Vija points to the extravagance nature of Eric's possessions and indicates the insignificance of their use value. His home exists primarily as a sign of value to indicate that he owns it In another occasion, she point to the fact that

all wealth has become wealth for its own sake. There is no other kind of enormous wealth. Mony has lost its narrative quality the way painting did once upon a time. Money is talking to itself ... The concept of property is changing by the day, by the hour. The enormous expenditures that people make for land and houses and boats and planes ... Property is no longer about power, personality and command. It's not about vulgar display or tasteful display. Because it no longer has weight or shape.” (DeLillo, 2003, p. 33).

It is according to this logic of consumer society that Benno says,

I thought all these other people. I thought how did they get to be who they are. It's banks and car parks. It's airline tickets in their computers. It's restaurants filled with people talking. It's people signing the merchant copy. It's people taking the merchant copy out of the leather folder and then signing it and separating the merchant copy from the customer copy and putting their credit card in their wallet. This alone could do it. It's people who have doctors who order tests for them. This alone" he said. "I'm helpless in their system that makes no sense to me. You wanted me to be a helpless robot soldier but all I could be was helpless. (DeLillo, 2003, p. 78)

Therefore, in his organization of different forms of value, Baudrillard suggests that there are four logic of social value: functional logic of the use value which is based on utility, economic logic of exchange value which is based on equivalence and, finally, symbolic logic of exchange which is based on ambivalence (Baudrillard, 1981, p. 63). 


\subsubsection{Sign}

Another dominant argument of Baudrillard regarding observation of consumer society is "sign value". Baudrillard believes that object begin to exist when they are liberated and function as the signs and this liberation is the result of the passage from industrial society to techno-culture (Baudrillard, 1981, p. 65). Douglas Kellner in Jean Baudrillard: From Marxism to Postmodernism and Beyond suggests, for Baudrillard modernity was concerned primarily with the production of objects, while postmodernism is concerned with simulation and the production of signs: "Modernity thus centered on the production of things - commodities and products - while postmodernity is characterized by radical semiurgy, by a proliferation of signs" (Ibid. pp. 8-19).

According to Baudrillard, sign, "as an agent of abstraction", renders itself as meaningful, rational, positive and exchangeable since "it begins to be posed beyond its status as a product and as a commodity" (Baudrillard, 1981, p.185; Horrocks, 1996, p. 43). This is in contrast with the traditional mode of object in which "objects are bound together and not liberated, have no status of their own and do not form a system among themselves" (Ibid.). Whereas, in postmodern society, sign assigns social rank and differentiates between the subjects. As a result, everything reduced to a sign and its value is determined by its place in system of objects and in its relation to all other signs within the system (Baudrillard quoted in Schuster 94).Baudrillard claims that, in fact, it is the logic of the sign that restricts subject's ambivalence in relation to objects and compels subject to lose ambivalence toward objects and relate to them in terms of positive sign value (Schuster, 2008, p. 25).

Therefore, unlike Veblen that claims, "conspicuous consumption" and display of commodities are confined to the upper social class, Baudrillard argues that in consumer society, it is the entire fabric of society that is organized around consumption and display of signs and by which one gains prestige, social standing, and identity. In this system, the more prestigious one's commodity- car, house, clothes-the higher one's status in the realm of sign-value (Kellner, 1989, p. 12). For Baudrillard, sign "is never given or exchanged: it's appropriated, withheld, and manipulated by individual subjects as a sign, that is, as a coded difference. Here lies the object of consumption. And it is always of and from a reified abolished social relationship that is "signified" in a code" (Ibid. p. 65).

According to Baudrillard, consumer society are formed by hierarchies of sign value in which one's social status and prestige are determined by where one stands within the semiological system of consumption and use value (Sarup and Raja, 1996, p.108). Therefore, the object of political economy must be conceptualized as a sign as well as a commodity; thus, it is through object that a stratified society appears (Ibid. p. 108). Baudrillard believes that consumption is a process in which sign values are consumed, that Marx's fetishism of commodities is not restricted to certain goods, but engulfs entire system of social prestige and differentiation (Ibid.).

Baudrillard's criticism of Marx, in another words, concerns the change from the production of objects to the production of signs, from the means of production to the means of consumption or, "the simultaneous production of commodity as sign and the sign as commodity" (quoted in Norris, 2005). Marxism presents a theory of use value and exchange value and the relationship between them but, for Baudrillard, Marxism fails to theorize about sign value, and systems with symbolic forces such as language and culture (Pawlett, 2007, p. 22). Baudrillard asserts that, in consumption generally, "economic exchange value (money) is converted into sign exchange value (prestige, etc.); but this operation is still sustained by the alibi of use value" (Baudrillard, 1981, p. 112).

The fact that everything within consumer culture signifies value, Baudrillard asserts, applies to people as well. Indeed, because people can be reduced, they are also commodities themselves, hence; define themselves in terms of the commodities they own. As signs of value themselves, engage in meaningless exchange of signs. We no longer address each other as individuals but as commodities; we are signs trading signs within the system of signs. This notion applies to Eric and his treatment of his employees; "He did not look at Shiner anymore. He hadn't looked in three years. Once you'd looked, there was nothing else to know" or when he ruminates about people and the fact that "They were here to make the point that you did not have to look at them"(DeLillo, 2003, p. 3, 8).

\subsubsection{Symbolic \&Exchange Value}

In sign value, on the other hand, there is double reduction- that of exchange value and of symbolic value and their transformation into sign value (Baudrillard, 1981, p.112). It should be added that in his consideration of logic of use value, Baudrillard claims that use value is an alibi for exchange value; it is a fiction assigned by system of commodity exchange, use and need. Therefore, as Marx critiqued exchange value, Baudrillard critiques use value. For Baudrillard, use value further integrates us in the system of exchange value and consumption. Another criticism is for accepting the idea of need as given. Baudrillard believes that the principle of need is the ideological construct of the Capitalist system (Ibid. p. 86). In regard to object of exchange, with reference to primitive societies' gift-exchange ceremonies like potlatch and kula, Baudrillard asserts that, the object is not only an object; it is indivisible from the exchange relation. Exchange contract is agreed upon between two people: therefore it is not independent. It is not only the embodiment of a relationship of desire, but by the objects uniqueness, it signifies the transparency of social relations in a group relationship (Baudrillard, 1981, pp. 44-65).

What designates an object the symbolic value is that "one separates himself from it in order to give it, to throw it at the feet of the other, under the gaze of the other, one divests himself as if of a part of himself . . The ambivalence of all symbolic exchange material derives from this: the gift is a medium of relation and distance; it is always love and aggression" (Ibid. p. 65). Baudrillard claims that symbolic order, by its irruptive power, splits from the capitalist norm 
of production and commodity exchange and in comparison with social logic of use value and exchange value is "neither law nor value but anti-value or anti-economy" (Ibid. p. 22).

Baudrillard claims that, the system like God can secure or release energies; but what it is unable to do is reversibility. Reversibility alone therefore, is dangerous for any system. This is what the term symbolic 'exchange' means (Baudrillard, 2000, p. 5).As Eric's final conversation with Benno shows, the nearness of death allows symbolic exchange to happen within consumer culture. Although consumer culture may preclude us from death, not in its biological form but as social relation, continues to haunt our everyday lives (Ibid. p.131). This idea is made clear through whole novel as Eric in his odyssey to get haircut gets engaged in betting against Yen, gets stuck in traffic by funeral procession, president's visit to city and anti-globalization protests. All these, along with slow movement of narrative, hinder the imminent occurrence of death.

In order to establish a meaningful communication, Baudrillard argues, there must be a mode of exchange that functions independently from the arbitrary code of value that organizes consumer culture (Baudrillard, 2000, p.116). Baudrillard calls, in Symbolic Exchange and Death, this mode of exchange as "symbolic exchange" (Ibid. 43). As a result, the logic of symbolic exchange requires that one side must lose what the other gain, which in the case of Cosmopolis Eric loses his life to Benno. Because consumer culture is so relied on the exchange of signs, yet symbolic exchange and death are virulent to the system. Hence, Eric as representative of the system by his own voluntary death and Benno by his symbolic act of resistance both destroy the fabric of consumer society. The final encounter between Eric and Benno brings Baudrillard's distinction between signification and symbolic exchange home when he says, symbolic exchange brings people together -which is the act of death in Cosmopolis- "the last purpose of signification is to identify social rank, and therefore to make differentiation, because many of Eric's conversations with Benno functions according to the logic of signification (i.e. as a means of differentiation for the sake of signaling social value) " (Baudrillard, 1981, p. $65)$.

\subsubsection{Symbolic Exchange}

Symbolic exchange is one of Baudrillard's key concepts as being one of the fundamental ideas in his understanding of the modern and postmodern societies. Symbolic exchange provides a springboard for understanding his later crucial concepts such as seduction, ecstasy, and his theory of the media. In theorizing and conceptualizing symbolic exchange, which he elaborates and analyzes in detail in The Symbolic Exchange and Death (1976) and For A Critique of the Political Economy of Sign (1981), Baudrillard employs cultures of primitive societies by drawing on the anthropological concepts such as Marcel Mauss's concepts of gift exchange, George Bataille's concept of general economy and the works of other anthropologists like Emile Durkheim, Pierre Klossowski, and Roger Caillois.

For Baudrillard, the crucial difference between consumer society and pre-modern society lies in the fact that "once collective, festive, ceremonial forms of wastage are now individualized, personalized and mass-mediated" (Pawlett, 2007, p. 21). According to Pawlett, symbolic exchange is a form or principle rather than a fixed content of a cultural practice (48). For Baudrillard, symbolic exchange is embodied in "acts, gestures, rituals, behaviors that demand a response from the economic/semiotic system" (Ibid. p. 48).

In Baudrillard's conceptualization of symbolic exchange, the defining and organizing center of symbolic exchange is death. In effect, the whole foundation of symbolic exchange is based on the concept of death and loss. Mauss's idea of primitive societies' gift and counter-gift plays a key role in Baudrillard's constitution of symbolic. Baudrillard claims the gift consumer system presents is an unanswerable gift which can only be returned by the unanswerable counter-gift of death. It is an effective means of subverting consumer ideology but it does not confront it on the "terrain of reality, which is always the reality of the system", but in terms that system cannot respond except by its own death (Baudrillard, 2000, p. 36 original emphasis).

Because the reality of symbolic exchange is that it "attacks, undermines, annuls or suspend" the very structure of the system and demands a response from economic/semiotic system, It functions as a threat to system because system burgeons when it would be able to function as if it is "complete, total and closed" (Pawlett, 2007, p. 48). Baudrillard claims "The universe . . . moves toward extremes and not toward equilibrium. It is devoted to radical antagonism and neither to reconciliation nor synthesis, such is also the principle of evil and it expresses itself in the ecstatic form of the pure object, in its victorious strategy overt the subject" (Baudrillard, 2001, p.185).

At the core of his ideas, lies the supremacy of objects over subjects, their proliferation, and the final triumph of object over subject. Baudrillard in "Ecstasy and Inertia" discusses how objects and events in contemporary society surpass, grow and expand in power. The ecstasy of the object is their "proliferation and increase to the nth degree, to the superlative" (Kellner, 1989, p. 156). Thus ecstasy is as "going outside of or beyond oneself; the beautiful as more beautiful than beautiful in fashion, the real more real than the real in television". It is " that quality specific to each body that spirals in on itself until it has lost all meaning, and thus radiates as pure and empty form. Fashion is the ecstasy of the beautiful: the pure and empty form of a spiraling aesthetics. Simulation is the ecstasy of the real" (Ibid.).

Therefore, his first theoretical shift, or better to say, rupture is from symbolic exchange to seduction, which posed a threat to the system of code and simulation. And his second shift is undertaking of the supremacy of the object and taking its side (Kellner, 1989, p. 176). This notion and this swerve from previous principles of thought in Baudrillard oeuvre, pose a question as to the role of symbolic exchange and its relation to the world dominated by object. In response, Baudrillard tells how he has abandoned the finality of transgression through symbolic exchange, for he now considers symbolic exchange as the strategy of the subject because object itself takes the first move toward reversibility. 
Because of these interpretations about objects in consumer society, in the following parts, this matter is examined in two parts, Object as Commodity and Object as Code.

\subsection{Object as Commodity}

In fact, for Baudrillard the essential characteristic of the consumer society is the proliferation of commodity signs that through which objects gain new importance and significance. Commodities for Baudrillard is both signified and signifier which have the features of "abstraction, equivalence, and interchangeability"(Kellner, 1989, p. 21). According to this theory, commodities constitute a system in which exchange value along with commodity sign form system of values in which one individual or good can be replaced with another. Thus, Baudrillard suggests that commodities are governed by rules, codes into a system of sign values. Then, to Marx's analysis of the commodity and its use value and exchange value, Baudrillard further adds the feature of sign value. Commodities are not the means of satisfaction of needs, as Marx's political economy claimed, but imply social meaning and prestige, which function as a statement of social standing in consumer society. This theory suggests that some objects or brands are chosen over others because of their sign value- that is, their relative prestige over other brands or types of commodities (Ibid. p. 22). This constant interaction with objects and living among them has, nevertheless, consequences and impacts on human life as Baudrillard utters that

Just as the wolf-child becomes a wolf by living among them, so we are ourselves becoming functional objects. We are living the period of objects: that is, we live by their rhythm, according to their incessant succession. Today, it is we who are observing their birth, fulfillment and death; whereas in all previous civilization, it was the object, instrument and perennial monument that survived the generations of men. (Baudrillard, 1998, p. 18. 2001, p., 29)

Baudrillard further claims in System of Objects that we cannot live in the real world with responding to each other as human beings since the objects we possess separate us from both (200). According to Baudrillard, the urge to accumulate and organize signs of social status is at the core of consumer ideology, therefore, any other logic or any other combination of goods cannot change its basic fact, which requires that we define ourselves in relation to the objects we possess (Schuster, 2008, p. 121). He argues, because we are surrounded by objects, we have become like objects and have come to behave like objects ourselves. It means that we no longer interact in a meaningful way with the world and the people around us; instead, we are among the world of objects that further detaches us from any real interaction (Ibid.).

Baudrillard, moreover, asserts that we have been so immersed in accumulating signs of "good living" that we can no longer have any connection with others in human terms. Consumer culture makes us believe that we can make ourselves appear valuable to others by accumulating objects and surrounding ourselves with valuable commodities. By measuring human worth in terms of value, consumer ideology places us in the same line with commodities, therefore; as a result, we become commodity as well (Baudrillard, 1996, p. 86).Baudrillard continues that this is but a big myth; the only freedom we have is to accumulate objects and commodities in a way that displays our social class and social status (Baudrillard, 1998, p. 61).

The very example of such thinking, therefore, is Eric's "forty-eight rooms apartment, lap pool, the card parlor, the gymnasium, shark tank and screening room, borzoi pen and annex" all function as signs of differentiation, affluence and insulation from the world (DeLillo, 2003, p., 4). Yet, it should be indicated that this insulation and isolation from the real world is the direct result of the proliferation of consumer goods and commodities in society (Baudrillard, 1998, p. 199).

The world DeLillo depicts in Cosmopolis, as his previous works, has many similarities with the world Baudrillard conceptualizes throughout his oeuvre and symbolic exchange is not an exception. It is, specifically, symbolic violence of Benno, his dismantling of system (as embodied by Eric) that brings the concept of Baudrillard to the fore. Benno, the real force of resistance, initiates symbolic challenge in Cosmopolis.

This is the place Eric finds himself throughout the Cosmopolis; he is unable of any meaningful, real interaction with people and even his wife. All his communication is in terms of commodity and objects. "What are we going to talk about?" she said. . . He realized her question was serious. We want a heliport on the roof. I've acquired airrights but still need to get a zoning variance. Don't you want to eat?". . . "And a shooting range next to the elevator bank" (DeLillo, 2003, p. 6).

Unlike Benno, Eric has alienated from any real sense of need and has lost touch with the real world. In fact, the world Eric lives is the world of imagined needs and because these needs are imaginary, the commodities that he possesses don't satisfy his real need and have no real purpose. The very instance of it is his "forty-eight room apartment with its lap pool, the card parlor, borzoi pen, the gymnasium, shark tank and screening room and atrium" (3).

Benno, being another example of Baudrillardian thinking of DeLillo, remains a zero in society of consumption. As a zero, he lacks value and this lack of value is what prevents him from being both a sign and an object. As a result, when he cannot ascend in the order of the objects, he plans to destroy that order. Eric by his "lively, basic denial of value", by his "latent violence toward the principle of identity and equivalence . . . in the last instance" assures his subjectivity (Baudrillard, 1981, p.208) 


\subsection{Object as Code}

As another aspect of consumer society, Baudrillard, moreover, introduces code as a system of complete abstraction. It no longer refers back to any reality but its own logic; it is the code that sets everything in advance, of conformity, revolt, playfulness and sexuality. Code is illegible, it cannot be read it is instead the form that allows reading to take place (Hegarty, 2004, p. 48). Code, then, is a collective and unconscious social constraint, a morality that Baudrillard seeks to expose (Pawlett, 2007, p. 13). Code that regulates signification has no relation to lived experience of humans; rather, code's authority is derived from the abstract and artificial concept of value (Schuster, 2008, p. 76). It is divisive aspect of code that signifies signification and renders signs "a coded, stereotyped version of reality" (15).

To bring an example from the novel, it is the code and its regulations that governs and controls Eric and Benno's relationship. It bears no relation to reality and their real lived experience. In fact Baudrillard claims that when death is approaching, conversation takes on enhanced significance. Therefore, Eric's conversation with Benno is symbolic because one of its basic assumptions is that Eric will die soon. Since these are Eric's last words, so they are indicated by ambivalence. Eric's last words and memories speak of love and impending loss, but more importantly, it cannot be exchanged in the casual conversation. As these conversations are his last words, they don't have any substitute and no equivalent. As the symbol of system, Eric must give his life without expecting any other things.

\section{Consumer Culture}

To determine the specification of a consumer culture, Baudrillard focuses on the downside of consumer culture and argues that the relationship between people and the objects which constitute their world complicates individual's subjectivity (Baudrillard, 1996, p.191). He claims that consumerism tries to assimilate and homogenize individuals within the parameters of the system of objects. There is this illusion that we have freedom in society through our purchases (Ibid.).

Mark Schuster claims that this notion derives from the fact that Baudrillard believes everything within consumer culture has been reduced to mere signs of value. Under this condition the only capability for meaningful communication has been reduced to only accumulating and displaying signs of affluence.

Baudrillard insists on the totalitarian nature of consumer ideology and claims that subject has no power to alter consumer logic and falls into lines as an object within the system of consumer system. For Baudrillard, the only way to change society for better is "to reveal all forms of value as illusory"(Schuster, 2008, p. 3).Such revelation, he argues, will start the collapse of consumer regime and, as a result, will allow individuals to consider themselves not as objects but as subjects and as an agent of change (Ibid).

But there are some shortcomings in his theory; As Douglas Kellner points in Jean Baudrillard: From Marxism to Postmodernism and Beyond, "Baudrillard has no theory whatsoever of the subject as an active agent of social change. Nor does he have a theory of a class or group revolt, or any theory of political organization, struggle or strategy" (18). Mark Schuster claims that the reason why Baudrillard cannot present such theories is that "his arguments deny agency altogether insofar as individuals, in his estimation, can only behave as objects within the confines of consumer culture".

For Baudrillard, individuals are unable to cause any social change because they can only behave according to parameters set for them by consumer ideology; since as objects, they are incapable of any change themselves (Kellner, 1989, p. 3-4). On the other side of the spectrum is DeLillo who shares Baudrillard's interest in consumer culture and has reflected at length on the relationship between individuals and objects that surround their environment (Ibid).

Through all of DeLillo's novels, as Frank Lentricchia notes in Introducing Don DeLillo, "commodities and other signs of consumer culture do not serve as mere props; rather, they are of the essence. That is, DeLillo's novels present consumer culture not just as a backdrop but as a matrix of contemporary values by, through and against which his characters struggle to define and redefine themselves and, in so doing, reshape the culture that attempts to define them" (6).

Unlike Baudrillard, DeLillo portraits a world in which subjectivity remains intact and the subject has the ability to change the ideological logic of society (Schuster, 2008, p. 4). According to Lentricchia, DeLillo writes in a mode that "marks writers who conceive their vocation as an act of cultural criticism; who invent in order to intervene; whose work is a kind of anatomy; an effort to represent their culture in its totality; and who desire to move readers to the view that the shape and fate of their culture dictates the shape and fate of the self" (2).

John Duvall, moreover, notes that DeLillo's novels challenge the authenticity of capitalism and its systematic control of the image by means media and advertising to form individual identity by individual's acts of consumption (Schuster, 2008, p. 4). Therefore, DeLillo offers solution but Baudrillard only sees problem (Schuster, 2008, p. 5). Yet, it should be indicated that both French theorist and American novelist critique the virulent effects of consumer culture.

DeLillo's novels, thus, demonstrate how our love of commodities has caused us to regard ourselves as commodities as well. Another point of contrast is that while Baudrillard sees artists as mere producers of consumer ideology, DeLillo considers art and artists as agents of ambivalence. He sees art as a force which has the power to reshape that culture (Schuster, 2008, p. 7).

In addition to his symbolic act of confronting Eric directly and personally which strikes a blow to consumer culture, he has not been homogenized into consumer ideology and its exchange of signs. He "works offline" and wants to "make a public act of life" through writing. He also has a very symbolic relationship with his petty belonging. He acts based on 
the knowledge that "the object is nothing and that behind it stands the tangled void of human relations" (Baudrillard, 1996, P. 196) when he says,

"I thought all these other people. I thought how did they get to be who they are. It's banks and car parks. It's airline tickets in their computers. It's restaurants filled with people talking. It's people signing the merchant copy. It's people taking the merchant copy out of the leather folder and then signing it and separating the merchant copy from the customer copy and putting their credit card in their wallet"(DeLillo, 2003, p. 86).

As another example, protestors in the street challenge the system by its own signs which are vital to the system and help to strengthen the system. This notion is further proved by Vija as she says, "The market culture is total. It breeds these men and women. They are necessary to the system they despise. They give it energy and definition. They are market driven. They are traded on the markets of the world. This is why they exist, to invigorate and perpetuate the system" (40).

Benno challenges the system by giving the opposite of what system wants; it means Benno avoids playing by the rules of the system. He must be confronted directly as he would by Eric. Here it should be indicated that one of the dominant features of consumer society is assimilation and homogenization of subject into the constellation of objects and into the ideology of the system of values. Therefore, yet another difference between Benno and protestors is that protestors have been absorbed and assimilated into the system of value of society and use sign value of the system they oppose.

But it seems that Eric, on occasions, experiences the sense of mutual connection with Benno Baudrillard sees operating in symbolic exchange. But this sense of connection is always short lived. In fact it is in this part that he feels his connection to the physical world. As one of the characters in Names asserts, "American style of murder is like all forms of exchange within consumer culture: cold, impersonal, and disconnected from any real sense of reality insofar as the victim is not an individual but an image or a sign" (quoted in Schuster, 86).

Benno final encounter and conversation with Eric is, in fact, a "dual, personal relation with the opposing power" (Gulf war didn't happen, 25, 26). It creates in Eric a "sense of warmth, of human involvement" that is unique throughout the novel (DeLillo, 2003, p.199). This face-to face interpersonal conversation that Eric and Benno engage belongs to the realms of symbolic exchange. This is in exact contrast with Eric's lifestyle in which everything was signs of social ascendancy. They engage in something more than sign exchange. In fact they replace "the arbitrary, disengaged, and calculating logic of sign exchange with the mutually binding sense of loss that characterizes symbolic exchange" (Schuster, 2008, p. 87).

In fact, Eric comes close to himself as he loses his possessions and as he approaches the Hell's Kitchen and at the final crucial encounter with Richard Sheets a.k.a. Benno Levin got invigorated and also causes invigoration for Benno as well. As the final lines of first part of the Cosmopolis reads:

The credible threat was the thing that moved and quickened him. The rain on his face was good and the sour reek was fine and right, the fug of urine maturing on the body of his car, and there was trembling pleasure to be found, and joy at all misfortune, in the swift pitch of markets down. But it was the threat of death at the brink of night that spoke to him most surely about some principle of fate he'd always known would come clear in time. Now he could begin the business of living. (107, emphasis added)

\section{Conclusion}

It is worth stressing that there are some convergent and divergent opinions on the role of individual in system of consumption between DeLillo and Baudrillard. While Baudrillard in whole his oeuvre generally and in Consumer society specifically, claims that there is no escape from alienation, from code and from ideology of consumer society; that the code prevents possibility of any true revolution, DeLillo's conviction is that there is hope for any revolution, for any change and for individual to take action and distance himself/herself from society and achieve individual freedom even under the constraints of media-saturated and technologically structured postmodern spectacle.

According to Marc Schuster, where Baudrillard asserts that acts of terror have the ability to achieve symbolic exchange, DeLillo believes that terror- in case of Cosmopolis, the terroristic act of Benno killing Eric- only escalates reproducing of the code of value that Baudrillard strives to destroy it (76).

To conclude, it should be said that for Baudrillard, as a theorist of consumerism, consumption is a social order regulated by code which is the governing principle of modern system of society of consumption. Surrounded by countless numbers of objects, humans have lost their meaning, identity and human relations and have become object themselves. They consume signs of social value, rank and differentiation. But the value that consumer society emphasizes "is nothing and behind it stands the tangled void of human relation" (Baudrillard, 1998, p. 196).

Baudrillard claims that the notion of use value and exchange value merge together to form an ideological shield against the symbolic order that causes ruptures to the system of code and suspends, undermines workings of use-value and exchange-value. In fact, he believes that use value is an alibi of exchange value and is an ideological myth of capitalism. Continuing his line of inquiry into the logic of objects, Baudrillard notes that to supremacy of objects and their triumph over subjects would be to the exclusion of authority, subjectivity and autonomy of the subject. He calls this notion as fatal strategies and claims that in order for the subject to thrive within the system of objects, he/she must take the side of the object and adopt its strategies and ruses. 
Yet against this gleam scenario, Baudrillard suggest that the only way possible out of this tragedy is by the means of symbolic exchange which is "neither a conception, an agency, a category, nor a structure, but an act of exchange and a social relation (Baudrillard, 2000, p. 133). For Baudrillard, the highest form of social relation is symbolic which is based on mutual need, loss love and aggression. But it is that which is excluded from use-value and exchange-value-as it is ambivalence. It subverts the supremacy of code and object and dismantles the ideology of value and returns real lived experience in human relations and communication.

\section{References}

Armitage, J. (October, 2007). Baudrillard's Successful Assault on Sociology. International Journal of Baudrillard Studies 4.3 http://www.ubishops.ca/baudrillardstudies/vol4_3/v4-3-article6-armitage.html

Baudrillard, J. (1981). For a Critique of the Political Economy of the Sign. (Charles Levin, Trans.). New York: Teloes Press. Ltd.

Baudrillard, J. (1996). The System of Objects. (James Benedict, Trans.). New York and London: Verso.

Baudrillard, J. (1998). The Consumer Society: Myths \& Structure. (George Ritzer, Trans.). London: Sage publication

Baudrillard, J. (2000). Symbolic Exchange and Death. (Lain Hamilton Grant, Trans.). London: Sage Publication.

Bishop, R. (Ed.). (2009). Baudrillard Now: Current Perspective in Baudrillard Studies. Cambridge: Polity Press. .

DeLillo, D. (2003). Cosmopolis. New York: Scribner.

Hegarty, P. (2004). Jean Baudrillard: Live Theory. London and New York: Continuum.

Horrocks, C., \& Jevtic, Z. (1996). Introducing Baudrillard. Victora: Icon Books UK, Totem Books USA.

Kakutani, Michiko (2003). Headed Toward a Crash, of Sorts, in a Stretch Limo. Review of Cosmopolis. The New York Times, http://www.nytimes.com/2003/03/24/books/books-of-the-times-headedtoward-a-crash-of-sorts-in-a-stretch-limo.html

Kellner, D. (1989). Jean Baudrillard: From Marxism to Postmodernism and Beyond. California: Stanford University Press.

Lentricchia, F. (1991). Introducing Don DeLillo. Durham NC: Duke University Press.

Norris, T. (July, 2005). Consuming Signs, Consuming the Polis: Hannah Arendt and Jean Baudrillard on Consumer Society and the Eclipse of the Real. International Journal of Baudrillard Studies. 2.2 http://www.ubishops.ca/baudrillardstudies/vol2_2/norris.htm

Pawlett, W. (2007). Jean Baudrillard: Against Banality. London and New York: Routledge.

Poster, M. (Ed.). (2001). Jean Baudrillard: Selected Writing. California: Stanford University Press.

Sarup, M. \& Raja, T. (1996). Identity, Culture, and Postmodern World. Georgia: University of Georgia Press.

Schuster, M. (2008). Don DeLillo, Jean Baudrillard And The Consumer Conundrum. Youngstown, New York: Cambria Press.

Updike, J. (March, 2003). One-way Street. New Yorker.

http://www.newyorker.com/archive/2003/03/31/030331crbo_books1\#ixzz1sJAuIDsK 